\title{
Central Asia: Redefining its Cultural Roots
}

\author{
By Gönül Dönmez-Colin
}

Fall 2002 Issue of KINEMA

\section{CENTRAL ASIA: REDEFINING ITS CULTURAL ROOTS}

More than a decade after Independence, Kazakhstan, Kyrgyzstan, Tajikistan, Turkmenistan and Uzbekistan, the Central Asian Republics of the former Soviet Union are still trying to establish a solid continuation of their cultural heritage. During the period of transition, lack of legislation in relation to creative organizations has created confusion and insecurity in the cultural sector, which was augmented by a high level of criminality and a low level of wages.

In the previous regime, the Soviet State had provided steady finance for filmmaking and oversaw the education of the filmmakers and in return, controlled every aspect of filmmaking. Following Independence, a new culture began to develop in each of the States with very little creative dialogue with their neighbours. Economic crisis has had its repercussions on the film industries and state financed studios lost their support. Faced with serious social, economical and political problems, the arts are not the top priority of most of these new governments. Furthermore, despite promises of a democratic life and a sovereign state, officials often seem to rely on old Soviet methods in dealing with arts. Today creative filmmakers of the autonomous Central Asian countries are looking towards the West for finances and recognition.

\section{Kazakhstan}

Kazakhstan is perhaps the only Central Asian State which was not affected by the social, economical and ethnical turmoil that swept the former republics after the fall of the Soviet Union. Under the liberal policies of President Nursultan Nazarbayev, the country of sixteen and a half million inhabitants moved to free market economy faster than Russia and banks and co-operatives did not miss the opportunity to publicize themselves through high profile investments such as cinema. However, private sector withdrew when investments did not show profit. Some investors went under interrogation for money-laundering. As a result, film production has fallen considerably. State-owned Kazakh Film Studios have now practically stopped production. Private studios are obliged to re-evaluate their projects according to the dictates of the capitalist system.

The only film made in Kazakhstan last year was Jol (The Road, 2001) by Darejan Omirbaev, an important representative of the Kazakh "new wave"(1). Omirbaev's reputation in the West was established with two remarkable feature films, Kairat (1991) and Kardiogramma (Heartbeats, 1995) opening the doors for coproductions. His next film, Tueur à gages (Killer, 1998) was made with French money, so was Jol, his latest. Omirbaev's directorial debut, Kairat, is a film with no hope for the future. The protagonist is caught cheating during the university entrance examinations and loses his chance of a better life. He loses his girlfriend to a "dude" and subsequently, is beaten up by a lout whom he has masochistically provoked. And in his dreams, only Death appears.

Kardiogramma (Heartbeats, 1995) deals with the problems of linguistic minorities from the point of view of a monolingual Kazakh boy from the country who is to spent a month in a sanatorium in the capital where the majority speak Russian. The film depicts the sense of total isolation intensified by the pains of adolescence.

Tueur à gages narrates three stories of exclusion involving three ill-fated heroes. Marat, a driver in Almaty, runs into the Mercedes of a local nouveau riche and his simple life turns into a frightening nightmare. As the cost of repairs is beyond his means, he is coerced into borrowing the money with exorbitant interest from a Mafia gang-leader. Harassed by his creditor, he accepts a "contract": the cancelling of his debt in return for the killing of a journalist. Thus he becomes a "hired killer," a link in the chain of killings during an epoch of transition when few have a chance to live. The last episode uses as an effective metaphor the power cut which is quite frequent in Kazakhstan. However, there is a new baby born and the film ends with Marat's wife lighting a candle.

The story of this film "could only have been set in the time after perestroika. The job of the killer was created at that time," Omirbaev explains. "Jol is more about the inner life of a man, an artist." ${ }^{(2)}$ It is also 
not as time specific as the Killer. The protagonist of Jol is a filmmaker called Amir who is summoned to the deathbed of his ailing mother whom he had not visited for a long time. While he is driving, the road disappears in the rear view mirror as a past left behind before the camera focuses on his troubled face, which is devoid of energy.

Memories are all integrated. Past and present, the real and the imagined all become one on that long road to his natal village. His mind wonders to his editing room where the walls are decorated with posters of landmark films of the Kazakh "new wave" - Serik Aprimov's Aksuat and Ardak Amirkulov's Abai. In an auditorium where his film is supposed to have its first screening, Amir declares to the audience that a film is "...naked in front of an audience. No one judges a science project as good or bad. There is no objective way to evaluate a film..." and he concludes, "the hardest job of all is to be a director."

The projectionist mixes up the reels and puts a karate film. The worse part is that the audience prefers this film to his. At home, his son who wears a Michael Jordan T-shirt, watches the same kind of stuff on television and he is very upset when his father wants to watch a documentary on Dostoevsky. For all he cares, Dostoevsky is another bearded old man in a big book. When Amir finally arrives at his destination (shot in Omirbaev's natal village Akkol), his mother is already dead and buried. Uprooted from his traditions, Amir feels like a complete stranger among his relatives.

Omirbaev does not resort to technical decoders, such as black and white for the past, colour for the present. Everything blends and becomes one, as part of a man's life, a man coming to terms with his part, present and future at a crucial moment in his existence.

A tribute to Kazakh filmmakers, $\mathrm{Jol}$ is also a forceful statement on the film industry of Kazakhstan where state owned cinemas or distributors are relics of the past. Following Independence, most cinemas were closed. A number of modern cinemas have been opening recently, which are privately owned by young businessmen, but generally speaking, there is not much interest in cinema. Serik Aprimov explains. "Not only that they won't show any Kazakh films, they don't even show American films. Even Titanic did not generate any interest. Main TV stations buy old American movies for about $\$ 1000$ and keep showing them."(3)

Aprimov's latest film, Tri brata (Three Brothers, 2000) shows an old man who has lived all his life with the Communist illusion. When the children begin to believe his illusions, they are killed. "Dreams lead to tragedy," states Aprimov. "There is no place for illusion."

Ardak Amirkulov shows the city of Almaty shrouded by inertia in his latest film 1997: Rustem's Notes With Drawings (1999) produced by another important "new wave" name, Ermek Shinarbaev. The city's condition is likened to the insomnia suffered by the citizens of Makondo in Gabriel García Márquez' novel, One Hundred Years of Solitude when exhaustion from lack of sleep causes amnesia. According to the director, "Soviet period was a lie. The lie has been exposed. Now there is no faith in the future. Other scale of values prevails, predominantly money." ${ }^{(4)}$

\section{Kyrgyzstan}

Aktan Abdykalykov is an autodidactic filmmaker who has been internationally acclaimed with his "growingup" trilogy that began with the medium length Selkintschek /Kacheli (Swing, 1993), followed by two features Beshkempir (The Adopted Son, 1998) and Maimal (The Chimp, 2001). Beshkempir, a sensitive story about an adopted son's search for cultural identity, focuses on the dramatic effects of the ancient custom of offering babies from large families to childless couples, on a young village boy. Following deep-rooted traditions, five old women pass the baby over their lap and name him Beshkempir (meaning "five women"). At adolescence, the world of the boy turns upside down when he finds out that he was adopted. Shot in black and white with occasional colour in certain scenes, the film reflects the visual beauty of Kyrgyz village life with remarkable insight.

Maimil (The Chimp, 2001), which was produced with finances from France is set in a dismal town in the wasteland of Kyrgyzstan where youth hang around aimlessly until they are recruited to the army. Alcoholism is shown as the main force behind the disintegration of the family in this autobiographical film about the director's own youth in a similar village.

Co-scripted with Tonino Guerra, a key collaborator on screenplays for Fellini and Tarkovsky, the film uses 
mirrors to reflect the soul of the protagonist and the point of view of the artist. When the alcoholic father loses the battle against himself, he turns the mirror around to avoid facing his reflection. The only thing left for him is to shut down his soul. In this film which he shot in colour, Abdykalykov, who was a painter before becoming a filmmaker, manipulates the colours aptly to reflect changing moods. Interesting to note that in all three films, the protagonist is played by Abdykalykov's son, Mirlan.

Abdykalykov's talent is also manifest in a remarkable short film, Beket /Ostanovka (Bus Station, 1995/2000) which he co-directed with Ernest Abdyshaprov. This is a black and white work that shows three people of different ages waiting for the bus on a very cold winter day. The old man sits on the bench and plays with his musical watch, the middle aged man fidgets in his place and the young boy keeps kicking a can. A woman arrives. A singing drunk bothers the woman. The middle-aged man protects her and makes her acquaintance. The drunk throws the old man's watch into the snow-covered fields. Then he begins to sob. The boy finds the watch. The woman consoles the drunk. We hear the crisp snow and feel the cold and the feeling of waiting and the feeling of desperation thinking the bus will never come as vehicles keep going in the other direction. But we never really see the faces. The subjective camera distances itself from the characters that are anonymous, almost like shadows. The film uses minimalist visual language to create a metaphor for the situation of the country. Abdyshaprov comments: "Beket /Ostanovka is about Kyrgyz people after "the break up. They are near a big road and waiting. For what? Cars come and go, but they are still waiting." ${ }^{(5)}$

The conditions for the filmmakers are not any better. The film studios are state-owned, but the government is not in a position to help the film industry. Gennady Bazarov, a prominent Kyrgyz director has not made any films since 1989. "There are people who want to see Kyrgyz films, but many problems exist," he explains. "First, the cinemas are very old. Second, those that work show Hollywood films, action and pornography. Third, many people are so poor, they can't go to the cinema at all. A new law has just been signed by the president about a little aid to cinema; it is small but symbolically significant to help people understand that art is important." ${ }^{(6)}$

"We want economic reforms to change our system," explains Abdyshaprov. "We understand that we are going through a difficult period. Perhaps one day the attention of the government will turn to us. In the meanwhile, we make videos to survive. In the Soviet era, Kyrgyzstan made three films per year. After perestroika, we made more because directors could find rich sponsors. In 1992, twelve long feature films were produced. But after that, it became more and more difficult. Between 1995-96, no films were made. Since 1996, we have been producing one film in two years, but this year two feature films have been made: Aktan Abdykalykov's Maimal, produced with French money and Marat Sarulu's Altyn kyrghol (The Silk Road, 2001)."

Co-productions appear to be the only light at the end of the tunnel, but they also come with a price tag. According to the Kyrgyz Film Studio head Tinay Ibragimov, there is a serious problem of commercial persuasion to focus on national topics when the money comes from abroad: "They want to tell you how your film should end. The relationship between the film and the spectator and the one who gives the money and the censorship is difficult." Beshkempir, which is said to have won 28 international awards so far, was distributed in several countries through its French partner. Although it was not a favourite in its own country, the industry profited from its international success.

Just like the rest of the world, Hollywood films are the most popular in Kyrgyzstan. "We understand that Kyrgyz film industry cannot produce commercial films and cannot compete with Hollywood," admits Abdyshaprov. "First there isn't enough money and second, it is not our mentality. We can only make our traditional Kyrgyz cinema and develop intellectual films. We are in the process of finding our lost traditions and parallel to that trying to choose the best tradition to adapt to meet the civilization of the West."

Prior to Independence, would-be filmmakers studied in Moscow. There is hardly anyone with Moscow education working today. The Institute of Fine Arts in the capital Bishkek, which has a department of Film and Television, produced its first graduates, directors and cameramen, last year. However, they are only making video clips.

Political films directly dealing with the Soviet era are conspicuously absent. "We got a good education 
studying there (VGIK-All State Film Institute in Moscow)," comments Baktry Karagulov, another important Kyrgyz filmmaker, "Why should we offend them? Of course we lost a little. We can't make films about how bad the Soviets were. We always had our culture. Why make a film about what does not exist? Thanks to Khrushchev, we have Aitmatov. We don't need anything artificial."

Eighty percent of Kyrgyzstan's four and a half million people live on US $\$ 2$ a day or less. Although Kyrgyzstan enjoys considerably better circumstances than its neighbour Tajikistan, extreme poverty, unemployment and the Afghan oriented trade in drugs and guns threatening order in more vulnerable areas are the issues of immediate concern. If people have to choose between buying a cinema ticket and buying bread, they naturally prefer to buy bread.

\section{Tajikistan}

Tajikistan is the poorest of the fifteen former Soviet Republics where very few people earn more than US $\$ 10$ a month. The economy and stability collapsed with Communism. Furthermore, from 1992 to 1997, the country was embroiled in civil war. There is a frail peace since 1997 when an agreement was signed between the Russian-backed government and the Islamic opposition to end the five years of civil war, but economic recovery has been very slow. The opium and heroin trafficking from Afghanistan through Tajikistan to markets of Eastern and Western Europe have had its repercussions on Tajik life. Illegal easy money has led to deterioration of moral values. Furthermore, there are reports of political assassinations.

Eminent filmmaker Davlat Khudonazarov, who received thirty percent of the vote in the presidential elections, had seen his message muffled by the control of the news media. Just like several other talented filmmakers who moved to Moscow or abroad, Khudonazarov has also left Tajikistan.

The most successful Tajik filmmaker today is Bakhtiyar Khudoynazarov who makes his films with foreign money and has them distributed in the West with much acclaim. His latest film, the Felliniesque Luna Papa (1999), was neither shot in Tajikistan nor produced with Tajik funds.

No feature films have been made in Tajikistan for the last ten years. In the last decade of the Soviet Union and early 1990s, video and audiocassettes became increasingly popular sources of entertainment as well as means of disseminating information outside government control. Today films are shown in city theatres and in villages on an irregular basis.

Short videos made by the new generation show depression and lack of prospects among the young. In Angel moi (Angel Mine, 2001) by Denis Walerjevitsch Beketov, a young boy dressed in white with the aura of a guardian angel follows an adolescent around with his video camera. The boy is kicked out of his home for skipping school for three months and shunned by his girlfriend who is getting drunk at a local bar. The only way out is suicide.

A documentary, Po tu storonu (The Other Side, Driver, 2001) by Oleg Jurevich Makarov is shot inside a reform school for the young. A little boy is there because he was begging on the street to pay for his sister's hospital bills. When she recovered, she ran away with her boyfriend and left the little brother to his own means. Despite all their misfortunes, the children try to retain their smile.

\section{Turkmenistan}

Turkmenistan, whose 500-km coastline on the Caspian Sea provides numerous natural resources, including oil and fish, is threatened by extreme levels of pollution, as well as fluctuating water levels. The government exercises an authoritarian democracy with tight control of the media. In comparison with its neighbours that are moving towards a market economy and social structures based on Islam, basic principles of the Soviet system still survive there. Close bilateral economic and military ties with Russia have been preserved, as the power of Turkmen military is very weak. Mafia controls the narcotics market and the illegal trade of several commodities. Living standards have dropped since 1991.

Initially, the President promised to finance five art films a year, as was the case prior to Independence. However, many talented filmmakers, from Khodzakuli Narliev ${ }^{(7)}$ to Sergei Shugarev have found themselves in conflict with the present regime. Narliev does not make films anymore. Shugarev who grew up in Turkmenistan with Russian parentage is in self-imposed exile in Russia. 
"Even though the republic's social system is considered democratic and nonmilitary, it is nevertheless autocratic with all the attendant, typical characteristics - the closed system, persecution of people who think differently, censorship and other delights," comments Shugarev. ${ }^{(8)}$ "Despite the outward harmony in society, you can feel that there is a danger of explosion, which originates in social, national and especially religious contradictions. The powers-that-be pretend it doesn't exist. It is dangerous to talk about it. The co-existence of different cultures as in Tajikistan won't work in the long run."

Government regulations now state that Turkmenian must be used as the predominant language in films and all post-Soviet films have been made without Russian synchronization "even though half the country speaks Russian," reiterates Shugarev whose Ham Hyyal /Aromat zhelany (Fragrance of Wishes, 1996) introduces Russian voice-over. Turkmenfilm Studio produces about four films a year, all of which are shot on video. Presently, there are no possibilities of shooting $35 \mathrm{~mm}$ films.

Do young people want to become filmmakers under such dismal circumstances? The Academy of Fine Arts has had its first graduates in artistic film last year. "Cameraman, directors for TV production and actors are trained at the Cultural Institute, but after graduation, they follow the same route as Kyrgyzstan, they make video clips," says Hammamet Kakabayev, an eminent filmmaker of the older generation.

\section{Uzbekistan}

Uzbekistan is a country rich in natural gas, coal, oil, gold and other resources. Among all its Central Asian neighbours, its economy now only stands second to Kazakhstan's. However, the market system has only given prosperity to a privileged few as the country tries to move away from the cotton monoculture (in place from the time of Stalin), which has brought tremendous environmental devastation. The standard of living has been falling down. People blame the new capitalism for their sufferings and Islamic fundamentalist movement is on the rise. Popular expectations after Independence for more pluralistic politics have been seriously thwarted.

Capital Tashkent with a population of two million people is the home of a modern, popular narrative cinema with strong social themes relative to the republic. Uzbek and Russian are the languages used in films. (During the Soviet period, films were shot in Russian and then dubbed to Uzbek for national release.) There is a variety of genre and style, from irony and farce to science-fiction and period pieces. Uzbek films are the most popular. Even Hollywood comes second.

The chief concern of the filmmakers is to meet the needs of their own people. "My aim is not to make films for festivals. Uzbek filmmakers shoot films for the twenty-three million Uzbek people," says Zulfikar Moussakov whose Bomba (The Bomb, 1995) and Yarathanga shukur (I Wish, 1997) are both situation comedies employing a great deal of irony in satirizing noble traditions and hypocrisies of daily life.

When confronted with the question of how it felt to become a filmmaker during a transition period, Moussakov responded: " I lived a big part of my life in the Soviet Union. No one asked me if I agreed with the changes. It was done by forces outside my control. Therefore my relationship to the break up is a philosophical question and my reaction is doing comedies with some humour because smile and hope are not present in our lives at this moment." ${ }^{(9)}$

Just as in the other states, among recent productions, there is an absence of political films dealing with the issue of coming to terms with the Soviet period, or an analysis of the present situation. According to the human rights group Helsinki Watch, Uzbekistan remains one of the last bastions of Communist style dictatorship on the territory of the former Soviet Union. Members of the opposition parties have been beaten on the streets or arrested on false charges. There is tight media censorship and a strict supervision of government personnel.

Moussakov does not agree: "I do not face any restrictions to make my films, but perhaps that is because I do not deal with politics. We don't only do children's films or comedies. Of course there are political films, but they are really historical. Everything that happened in our country until 1930s has made itself to the celluloid. During the Soviet period, we shot films about the 1930s and 1940s. Now we are reconsidering these topics and trying to understand what happened at that time. Presently, Uzbek Kino is shooting a film about the jadids ${ }^{(10)}$ who brought history to our people and another one about the February $16^{\text {th }}$ explosion 
in Tashkent - the attack on the President. ${ }^{(11)}$ I don't think there are taboos. This applies to politics. Of course we have censorship. Violence and sex are not allowed. We don't need them."

Yusuf Razikov, another Uzbek filmmaker and the Head of the Uzbek Film Studio, calls this "inner censorship," meaning auto-censorship. What other "inner censorship(s)" exist besides sex and violence? It is an issue more related to Uzbek culture according to Razikov who also concentrates on the genre of comedy but mixes it with reflections on social, moral and psychological issues. ${ }^{(12)}$ His feature films Voiz (Orator, 1999) and Ayollar Saltanati /Zhenskoe tsarstvo (Women's Paradise, 2000) have made the rounds of several prestigious film festivals and have won awards.

Orator, which he wrote and produced as well as directed, is a gentle satire on the battle of the sexes layered with subtle nuances about totalitarian regimes. Prior to the Bolshevik revolution, the hero, Iskander lives happily with his three wives, which is permitted by the Islamic laws of Sharia, but is contrary to the morals of the Bolsheviks. When he provides refuge to a wounded revolutionary fighter, he is nominated "national cadre" following their victory. An emancipated commissar named Ajdyn falls in love with him and tries to disperse his wives. Faced with the contradictions of the revolution, Iskander is unable to retain either his family or a clear conscience.

Women's Paradise, also written, directed and produced by Razykov is again a comedy about the battle of the sexes, at least on the surface. Olim, the artist is suffering from writer's block and having difficulties organizing his several relationships with several levelheaded women. The big question that faces him is whether to love one woman who stands for all women, or to love all women. The film uses magic, fantasy and a good dose of humour in searching for an answer to this question.

A filmmaker of the older generation who still makes films is Ali Khamraev, a VGIK graduate who is considered as one of the leaders of Uzbek cinema. He is the most versatile filmmaker who has made all genres of films to satisfy his curiosity and the demands of the authorities in the Soviet era and perhaps his foreign producers in the present. There is no genre he has left untouched - opera, musicals, westerns, children's films, comedy and history. ${ }^{(13)}$

The most recent work of Khamraev has created controversy in Central Asia. A co- production between Uzbekistan, Italy and France, $B o-B a-B u$ (1999) takes place in an unspecified time somewhere in Central Asia in the style of Scheherazade's tales. A young woman played by Arielle Dombasle, (Pauline of Eric Rohmer) loses her memory after a fall and remains mute. Two herdsmen capture and abuse her, forcing her to pray to their god. She becomes their possession but her presence marks a rupture in a delicate equilibrium as the stronger of the two claims her as his own. However, the lines of allegiance keep shifting in unexpected ways. While shot in the deserts of Afghanistan, $B o-B a-B u$ reflects an imaginary wasteland where the harsh and never-ending desert dominates life. It is all supposed to be a parable which, incidentally is undermined by the voyeuristic nude scenes and the graphic cruelty that offend many Central Asians who do not want the film to be released in their country.

Six feature films, forty shorts and animation are made each year with the support of the government through Uzbek Kino, a state joint company, which also takes care of the distribution. However, Uzbek films are not sold outside the country. They only go to festivals and cultural events. Co-productions are distributed by the partner. There are private studios as well but for financial reasons, they are limited to one or two films per year. Are there any ramifications of making films with state money, I ask Razikov. His answer is very practical. "If the State gives money for a film, the least it would expect is a film audience would like to see."

Do young people want to become filmmakers in Uzbekistan? "We have the Academy of Fine Arts, which will present its first graduates in artistic film this year," explains Moussakov. "Cameramen, directors, film and TV producers and actors are trained at the cultural institute. But after graduation, they follow the same route as in the rest of the former republics, they prefer to make video clips."

A look at post-Independence cinemas of the Central Asian States of Kazakhstan, Kyrgyzstan, Tajikistan, Turkmenistan and Uzbekistan shows that a new cinema is emerging with young filmmakers trying to find their path through a difficult transition period. In comparison to the Soviet regime when the industry was under the tight control of Moscow, there is a certain amount of freedom. However, sex and violence are still not permitted, except perhaps in Kazakhstan and auto censorship is exercised when it comes to controversial 
political subjects. Except for Uzbekistan, Hollywood films are the most popular. The biggest drawback to the development of the national cinemas, however, is the lack of money. As the eminent Kyrgyz writer and philosopher Chingiz Aitmatov aptly stresses, "The ideological censorship of the Soviet Union is now replaced with the censorship through money which is the reason behind the domination of the Western culture."(14)

\section{Notes}

1. A movement that was initiated by Russian filmmaker Serguei Soloviev who organized a workshop in Moscow in 1984 to train young Kazakh talents who later became important voices of post-Soviet Union Kazakh cinema. (See Gönül Dönmez-Colin, "Kazakh 'new wave': post-perestroika, post-Soviet Union," Central Asian Survey 16, No 1, March 1997.

2. Interview by Cloe Drieu in Aus dem Herzen der Welt-Das Kino der zentralasiatischen Republiken, Viennale/Austrian Filmmuseum, 2001.

3. Personal interview during the Rotterdam International Film Festival, 2000.

4. Gonul Donmez-Colin, "Being Young in Almaty" Cinemaya, Summer 1999.

5. Personal interview at FilmFestival Cottbus (1-5 Nov 2000). FilmFestival Cottbus in Germany devoted its Regional Focus to Central Asian Cinema of the 1990s with over twenty films from Kyrgyzstan, Turkmenistan and Uzbekistan in 2000 and Kazakhstan and Tajikistan in 2001. Chingiz Aitmatov is the patron of the festival.

6. Personal interview during Festival des 3 continents, Nantes, 2001.

7. Narliev's work, starting from his first film, Nevestka (Daughter-in-Law, 1972) to You Must Dare to Say "No" (1977) and Derevo dzamal (Jamal Tree, 1981) traces the historical development of Turkmen women.

8. Interview by Galina Antosschevskaja, 26th International Forum Catalogue of the 46th Berlin International Film festival, 1996.

9. Gonul Donmez-Colin, "Zulfikar Mussakov: Humour in the Absence of Hope and Laughter", Cinemaya 53 (2001).

10. The Reformist movement of 1913-16, which started in Central Asia with the strong influence of the Crimean Tatar intellectual and publisher, Ismail Bey.

11. A series of explosions occurred in the capital, Tashkent on 16 February 1999 for which President Islam Karimov blamed the "Islamic extremists and others who wished to undermine the government."

12. Gonul Donmez-Colin, "Yusuf Razykov: Imperfect Paradise," Cinemaya 53 (2001).

13. Some of the best known films of Ali Khamraev are Belye, belye ajsty (The White, White Storks, 1966); Chelovek ukhodit za pticami (Man Follows the Birds, 1975); Triptih (The Woman of Mevazar, 1978); Telohranitel (Bodyguard, 1980) and Ja tebja pomniu (I Remember You, 1986), dedicated to his father Ergash Hamrayev, famous Uzbek actor who died in the war.

14. The creation of a national cinema in Kyrgyzstan is customarily attributed to Bolotbek Shamshiev, Tolomush Okeev and Melis Ubekeyev whose protagonists are common men with everyday joys and sorrows. But the most important force behind Kyrgyz cinema is a writer and philosopher, Chingiz Aitmatov. He served as the president of the Union of Filmmakers for many years. Many of his books are made into films and he often collaborates in the writing of the scripts.

\section{Author Information}

Gönül DÖNMEZ-COLIN is an independent researcher and writer whose publications include Women, Islam and Cinema, Cinemas of the Other: A personal Journey with Filmmakers from the Middle East and Central 
Asia, Cinema of North Africa and the Middle East (ed.); Turkish Cinema: Identity, Distance and Belonging (Reaktion Books), and Routledge Dictionary of Turkish Cinema (2014). 